\title{
Semmelweis Egyetem I. sz. Sebészeti Klinika - Ultrahang labor
}

\author{
WINTERNITZ TAMÁS, ZSIRKA-KLEIN ATTILA, SZIJÁRTÓ ATTILA
}

Semmelweis Egyetem, I. sz. Sebészeti Klinika, Budapest

\begin{abstract}
A Semmelweis Egyetem I. sz. Sebészeti Klinika egyik sajátossága, hogy elsőként jelentek meg a sebészethez köthető, ma már rutinszerüen végzett beavatkozások, illetve jelenleg is éves szinten több száz ultrahangos intervenció történik erre képesített sebészek munkájával.
\end{abstract}

\section{Múlt}

Úttörő módon, haladó szellemiségként 1984-ben Szécsény Andor professzor eldöntötte, hogy szeretné bevezetni a klinikán az intraoperatív ultrahang diagnosztikát. A készülék megrendelése után $d r$. Winternitz Tamás a Radiológiai Klinikán féléves képzésen vett részt. 1986-ben érkezett meg klinikánkra egy PICKER LS 5000 ultrahangkészülék, hasi és két intraoperatív ultrahang-transducerrel, amellyel elvégeztük az első hazai sebészeti intraoperatív utrahangvizsgálatokat. ${ }^{1}$ Az első hazai intraoperatív UH-vizsgálat képe egy pancreasfeji insulinoma diagnosztizálásánál született meg.

A kezdeti időben csak mütőben használtuk a berendezést, azonban a későbbiekben különböző egyéb vizsgálatokat is elkezdtünk végezni. Flautner Lajos professzor támogatásával és forszírozására 1987-ben kezdtük el a pancreas-pseudocysták, -tályogok drainálását. Ugyanabban az évben kezdtük a szükös radiológiai kapacitás miatt az ultrahangvezérelt pancreas- és májbiopsziák végzését is az I. sz. Sebészeti Klinikán. 1988-tól a veseátültetésen frissen átesett vagy kontrollra érkező betegek ultrahangszürését kezdtük el, amelyet későbbiekben már $d r$. Weszelits Viola radiológus kolléganő végzett. A folyamatos ellátás érdekében $d r$. Fehérvári Imre és $d r$. Máthé Zsolt is megtanulta az ultrahang alkalmazását. A későbbiekben - az előző kollégáknak a megalakult Transzplantációs és Sebészeti Klinikára való távozásuk után - dr. Németh Zsuzsa, majd $d r$. Döngölő László is végzett ultrahangvizsgálatokat. Hosszabb ideig dolgozott az ultrahanglaborban $d r$. Zalaba Zoltán.

1989-ben megkezdtük az ultrahang- és endoszkópvezérelt kettős pigtail katéter beültetéseket $d r$. Éles Zsuzsanna gasztroenterológus segítségével.

1989-ben az országban először végeztünk májcystaleszívást, sclerotizálást, majd drainaget sclerotizációval. ${ }^{2}$

1990-től rutinszerüen történtek a klinika intenzív osztályán az ágy melletti diagnosztikus vizsgálatok, majd egyre nagyobb számban az intervenciók is, mely vizsgálatok a 2000-es évek elején elérték az 500 körüli számot, melyhez közel 300 ágy melletti intervenció társult.

1995-ben pályázati úton sikerült egy új, color-flow doppleregységgel felszerelt készüléket (Hitachi EUB 565A) beszerezni, melyhez endoszkópos ultrahang-transducer is csatlakoztatható volt. Ekkor történtek klinikánkon és az országban első alkalommal endoszkópos, ultrahangvezérelt mintavételek és punctiók. ${ }^{3}$

1996-tól a mütőben az átmenetileg laparoszkópos intraoperatív ultrahangkészülék elérhetősége biztosítottá vált, amit elsősorban laparoszkópos pancreasresectiók során alkalmaztunk.

$\mathrm{Az}$ ezredforduló után a klinika aneszteziológusai részéröl is növekvő érdeklődés jelent meg az ultrahang lehetőségei iránt. Intenzív osztályunkon 2000-ben végeztünk először centrális véna kanülálását. Ezt rutinszerüen 2003tól $d r$. Nagy Edina végezte. ${ }^{4}$ 2001-től endoszkópos ultrahang-, majd percutan ultrahangvezérelt ggl. coeliacum blokádot, lysist végzett $d r$. Borsodi Marianna.

2002-től dr. Járay Balázs patológus kollégánk az ultrahangrendelés alatt, majd 2003-tól önálló cytológiai rendelés keretében végzett cytológiai mintavételeket. A rendelés vezetője jelenleg $d r$. Székely Eszter. ${ }^{5}$

Az ultrahanglabor első 25 (teljes) évének teljesítményét 2012-ben dolgoztuk fel. 38957 diagnosztikus ultrahangvizsgálat mellett 6242 intervenció történt nem radiológus kezéből, úm.: máj FNAB: 1549; pancreas FNAB: 503; egyéb hasi biopsia: 287; diagnosztikus punctio: 1389; terápiás intervenció: 2011; centrális vénakanül: 503.

A növekvő igény, illetve a régi készülék elhasználódása miatt két Sonosite Titan készüléket vettünk a műtői és intenzív osztályos vénaszúrások, ágy melletti vizsgálatok céljára.

Az évek alatt a klinikáról 63 kongresszusi előadás, 9 közlemény és 4 könyvfejezet született az ultrahang-diagnosztikával kapcsolatban.

\section{Jelen}

A korábbi ultrahangos kollegák távozása után ismét kétszemélyessé vált az ultrahanglabor. Dr. Zsirka Attila 2003-tól kezdve egyre nagyobb aktivitással vett részt a 
labor munkájában. Növekvő számban végzett, végez intervenciókat. ${ }^{6}$ Zsirka $d r$. kezdte el a májtumor miatti v. porta embolizációhoz szükséges portapunctiók végzését, amelyböl napjainkig 245 történt. Az intenzív osztályon már nemcsak az „ultrahangosok”, hanem egyre több aneszteziológus végez ultrahangvizsgálatokat mellkasi folyadék, hasi folyadék vizsgálatára. Gyakorlatilag nem történik centrális vénakanülálás ultrahang alkalmazása nélkül. A májműtéteket végző kollégák mindegyike végez intraoperatív ultrahangvizsgálatokat.

A mütétekhez szükséges idegblokádokat is egyre gyakrabban ultrahangvezérléssel szúrják. 2013-ban TÁMOP pályázat révén egy Hitachi Hi Vision Avius készülékhez jutottunk, le tudtuk selejtezni a közel 18 éves gépünket. 2016-ban pályázati úton Hitachi mobil ultrahangkészüléket tudtunk venni, laparoszkópos ultrahangfejjel. Ugyancsak szélesítette a diagnosztikus fegyvertárunkat, hogy rectalis transducert szerzett be a Klinika, amellyel $d r$. Ónody Péter és dr. Ferreira Gábor kezdett napi szinten dolgozni.

\section{Jövő}

Valamikor a 1980-as évek elején számos kongresszuson elhangzott, hogy az ultrahang a jövő stetoszkópja. ${ }^{7}$ Napjainkra ez egyre inkább megvalósulóban van. A készülékek fejlesztése két irányban mozdult el: egyrészt az egyre szofisztikáltabb, egyre több szolgáltatást nyújtó „nagy” gépek felé, illetve a kis, akár zsebben is hordható mobil, gyakran egy-egy feladatra kifejlesztett, relatíve olcsó készülékek irányába. Az utóbbi készülékek beszerzését támogatja, tervezi a Klinika, hogy osztályonként, mütőblokkonként specializált készülékek elérhetőek legyenek. Ehhez az az igény is társul, hogy a felhasználók alaposan megtanulják az eszközök használatát. Nemzetközi tapasztalatok alapján ez a sebészképzésben megvalósítható lenne. Remélhetőleg hamarosan minden sebész szakorvos a szakképzés keretében alapultrahang-vizsgálatokra is feljogosító képzésben részesül majd.

\section{Irodalomjegyzék}

${ }^{1}$ Winternitz T, Flautner L, Harkányi Z, Tihanyi T, Szécsény $A$ : Az intraoperativ ultrahangvizsgálatok szerepe a hasi sebészetben. Orvosi Hetilap 1989; 26: 1377-1382.

${ }^{2}$ Winternitz T, Kupcsulik P, Flautner L: Polycystás máj ultrahang-vezérelt sclerotisatiója. Magyar Radiológia 1996; 70(1): 26-29.

${ }^{3}$ Winternitz T, Kokas P, Éles Zs, Kupcsulik P, Döngölö L, Flautner L: Gastroenterológiai endoscopos ultrahangvizsgálatok convex transducerrel. Orvosi Hetilap 1997; 138(2): 75-79.

${ }^{4}$ Winternitz T, Nagy E, Borsodi M, Zsirka-Klein A, Kupcsulik $P$ : Centrális véna kanülálása ultahang vezérléssel. Orvosi hetilap 2009; 150(14): 641-644.

5 Járay B, Turányi E, Szalay K, Winternitz T: Gócos májelváltozások ultrahangvezérelt vékonytủ aspirációs citológiája. Orvosi Hetilap 1997; 138(27): 1730-1736.

${ }^{6}$ Zsirka-Klein A: Ultrahangvizsgálat a sebészi diagnosztika, intervenciók támogatásában. IME 2012; 11(7): 36-42.

${ }^{7}$ Filly RA: Ultrasound: the stethoscope of the future, alas. Radiology 1988; 167(2): 400.

A cikk a Creative Commons Attribution 4.0 International License (https://creativecommons.org/licenses/by/4.0/) feltételei szerint publikált Open Access közlemény, melynek szellemében a cikk bármilyen médiumban szabadon felhasználható, megosztható és újraközölhetö, feltéve, hogy az eredeti szerző és a közlés helye, illetve a CC License linkje és az esetlegesen végrehajtott módosítások feltüntetésre kerülnek. (SID_1) 